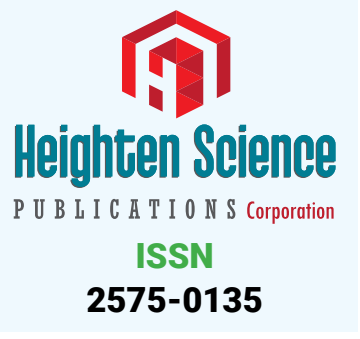

*Address for Correspondence: Rueda Puente Edga 0 , University of Sonora, Department of Agriculture and Livestock, University of Sonora, Blvd. Luis Encinas y Rosales s/n, col. Centro. C. P. 83000. Hermosillo, Sonora, México; Tel: (662) 5960297; 5960296; Email: erueda04@santana.uson.mx

Submitted: 18 September 2018

Approved: 01 October 2018

Published: 02 October 2018

Copyright: (c) 2018 Midega CAO, et al. This is an open access article distributed under the Creative Commons Attribution License, which permits unrestricted use, distribution, and reproduction in any medium, provided the original work is properly cited.

Keywords: Distichlis palmeri; Halophytes; Cereals; Salinity; Adaptation; Plant growth promoting bacteria

D) Check for updates

\title{
Bacillus amyloliquefaciens as a plant growth promoting bacteria with the interaction with of grass salt Distichlis palmeri (Vasey) under field conditions, in desert of Sonora, Mexico
}

\author{
Ruiz Alvarado Cristina ${ }^{1}$, Jesús Borboa Flores², Victor Cardenas \\ Salazar ${ }^{1}$, Soto Ortiz Roberto ${ }^{1}$, Lourdes Díaz Cervantes ${ }^{3}$ and \\ Rueda Puente Edgar $0^{3 *}$ \\ ${ }^{1}$ Institute of Agricultural Sciences of the Autonomous, University of Baja California, Mexico \\ 2University of Sonora, Department of Research and Graduate Studies in Food, Blvd. Luis \\ Encinas y Rosales s/n, col. Centro. C. P. 83000. Hermosillo, Sonora, México \\ ${ }^{3}$ University of Sonora, Department of Agriculture and Livestock, Universidad de Sonora, Blvd. \\ Luis Encinas y Rosales s/n, col. Centro. C. P. 83000 . Hermosillo, Sonora, México
}

\section{Abstract}

The halophyte Distichlis palmeri (Vasey) is a plant resource with high potential to be harvested in the coastal areas of northwestern Mexico; enlarge the knowledge and domestication for its incursion into the agricultural sector, plays an important role for arid areas with saline intrusion problems. However, its productivity depends on the supplementary supply of nitrogen, as well as other essential macro and micronutrients. The microorganisms considered beneficial are an alternative to chemical fertilization, highlighting those Plant Growth Promoting Bacteria (PGPB). In the present study, the inoculation of the Bacillus amyloliquefaciens (B.a.) as a halobacterium PGPB was evaluated to know the response in seeds of Distichlis spicata obtained from natural population from colorado river in Delta north of the Gulf of California. Wild seed was collected and germinated previously inoculated with B. a., and sowed in germinated beds. Later, seedlings were planted under field and salinity conditions in the coast of Hermosillo, Sonora. Three treatments were examined (T1: B.a., T2: Chemical fertilization, T3: Negative control), with four repetitions each treatment. Each repetition consisted of experimental plots of $5 \times 5 \mathrm{~m}$, with a separation of $1 \mathrm{~m}$ between them. The harvest was carried out 600 days after sowing. The results indicate that treatments inoculated with halobacteria B.a., showed significant results in crude protein, non-protein nitrogen, neutral detergent fiber and acid detergent fiber, as well as spike length and number of seeds. The results obtained suggests the feasibility of biofertilizers where biomass and seed production are significant compared to non-inoculated controls.

\section{Introduction}

The arid and semi-arid ecosystems in Mexico, represent approximately $60 \%$ of the surface of the national territory; they are places of high productivity indices for the economic and social development of the country $[1,2]$. Due to low rainfall and high evaporation in arid and semi-arid zones, a steady increase in the salinity of Sonoran soils has been observed. The implementation of recovery measures for these soils implies high costs, since it is necessary to build adequate infrastructure, as well as large volumes of water for their washes and the application of soil improvers. This situation has caused a large number of farms once they have salinity problems to be abandoned, leaving them totally exposed to degradation [3]. 
It is estimated that in Sonora, Mexico, 100 thousand hectares have been unproductive because they can not establish conventional crops efficiently, and one million hectares between desert and coastal areas affected by saline intrusion [4].

An alternative to conserve this important resource, as well as to take advantage of salinity, is the introduction of crops that can produce under these conditions. Such is the case of halophytic plants (salt tolerant), in particular of Distichlis palmeri or gentile wheat, a species that has been considered with great potential to produce grains under these conditions [5]. Salted grass Distichlis spicata is a non-native species domesticated from the family of grasses, native to the coasts of Sonora and Baja California Sur $[6,7]$, it is generally found green during the period of drought, while the rest of the forage grasses on the site are not available; for this reason, livestock consume it, even when at other times they do not want it [8]. Although it is considered invasive under certain conditions and uses, it is often desirable at sites where livestock activity is concentrated, because it is highly resistant to heavy trampling and grazing. Because Distichlis forage has been considered low quality, efforts have been made to replace it with more palatable and saline tolerant grasses, but the methods used have not been effective, because the profuse system of rhizomes it constitutes a strong limitation for the establishment of replacement pastures [9]. Its chemical content outlines a fibrous forage with low protein content and high mineral content, but when it is evaluated in a tender state, such as sprouts after a burn, its chemical values improve, increase the crude protein and maintain its fiber content [8-10]. The response of D. spicata to salinity has indicated that the yield and chemical content varies by the concentration of salt in the irrigation water or in the nutrient solution and by the type of soil. Lugg [11] concluded that salted grass has great potential to be irrigated with highly saline water when other forages are not available.

On the other hand, according to previous studies concerning the production of halophytes, the productivity of this type of plants is limited by the availability of nitrogen, which has an evident effect on its growth, reproduction and levels of nitrogen in biomass, among other aspects. A solution to eliminate this limitation would be the application of synthetic fertilizers. However, it often falls into an inadequate management and indiscriminate use, which affects in an important way the soil microflora, including beneficial microorganisms [12]. Among the microorganisms considered beneficial, those that are considered growth promoters stand out. These are characterized by being present in the rhizosphere and by their ability to fix atmospheric nitrogen and produce phytohormines $[13,14]$. These characteristics have a high impact on agricultural productivity since they can potentially reduce production costs by reducing or eliminating the use of chemical fertilizers [15]. Among the most studied microorganisms that fix nitrogen and/or produce of phytohormones are bacteria of the genera Azotobacter spp, Klebsiella spp and Azospirillum spp [16,17]. On the other hand, the genus Azotobacter spp and Klebsiella spp and Bacillus amyloliquefaciens are nonspecific for agricultural crops and the genus Azospirillum spp has specificity for pastures, but a high capacity to associate with vegetables such as tomato and chile and with cacti has also been reported [18,19]. One of the study models of plantmicroorganism interaction the one of plant-Azospirillum, since of the most outstanding effects, they are to promote in the different species of plants (grasses mainly), under soil conditions and different climates, an increase in the total weight, in the amount of nitrogen in grains and buds, number of stems, height of plant, germination rate, flowering and early appearance of the spike [15]. Azospirillum is conformed by the species A. brasilense, A. lipoferum [20], A. amazonense [214, A. irakense [22] and A. halopraeferens [23]. Notwithstanding the above, it is necessary to expand the knowledge of bacterial species associated with the rhizosphere of halophytic plants.

Based on the above information, the present study aimed at evaluating the inoculation of the Bacillus amyloliquefaciens (B.a.) halobacterium in Distichlis spicata to determine the response in field conditions with salinity problems in Sonora, Mexico 


\section{Materials and Methods}

\section{Seed collection and processing of treatments}

Mature and dry plants of the halophyte Distichlis palmeri (Vasey) were selected to obtain seed in the Colorado River Delta north of the Gulf of California (31 ${ }^{\circ} 54^{\prime} 53.38^{\prime \prime} \mathrm{N}$ and $114^{\circ} 57^{\prime} 18.00^{\prime \prime} \mathrm{W}$ ) (Figure $1 \mathrm{a}, \mathrm{b}$ ). In order to separate the mature seeds, the plants were macerated in dry and sifted (200). The seeds of greater size were selected, as well as of uniform color and without apparent damages. Three treatments were considered (T1: B.a, T2: Chemical fertilization, T3: Negative control), with four repetitions each treatment. Each repetition consisted of experimental plots of $5 \times 5 \mathrm{~m}$, with a separation of $1 \mathrm{~m}$ between them in experimental area of the study indicated in figure $\mathrm{b}$. The treatments fertilized in the field, was using as a source of nitrogen, urea ( $46 \% \mathrm{~N})$; and as a phosphorus source, triple superphosphate (46\% P). The fertilization dose was (N-P: 120-60).

\section{Inoculation with bacteria and seedling production}

Bacteria were grown in $\mathrm{N}$-free $\mathrm{OAB}$ medium containing $0.5 \mathrm{M} \mathrm{NaCl}$ [23]. Bacterial concentration was adjusted by dilution to $1 \times 10^{9}$ colony-forming units per milliliter (CFU $\mathrm{mL}^{-1}$ ) using a spectrophotometer (Master Spectrum, Fisher Scientific 415) when the culture was in the logarithmic phase $(15 \mathrm{~h})$. Each bacterium was deposited in a 250 $\mathrm{mL}$ Kitazato flask, and subjected to vacuum infiltration at $600 \mathrm{~mm} \mathrm{Hg}$ for $50 \mathrm{sec}$ [24]. Salted grass seeds prior to inoculation, were subjected to a disinfection, performing a dip in sodium hypochlorite for $30 \mathrm{~s}$ at a concentration of $3 \%(\mathrm{v} / \mathrm{v})$. The seeds were washed three times with sterile distilled water and then dried on sterilized absorbent paper. The inoculation was then proceeded as previously described according to the corresponding treatments. In the area of seedling production and field, the plants were inoculated every 30 days, depositing $1 \mathrm{~L}$ of bacterial solution to the corresponding plots at a concentration of $1 \times 10^{9}$ cells per $\mathrm{mL}$.

\section{Location of the experimental área}

This study was carried out in the Bella Vista agricultural field, located on Calle 36 on the Hermosillo coast, $90 \mathrm{~km}$ from the city of Hermosillo, Sonora, $15 \mathrm{~km}$ from the Gulf of California and at a height of $20 \mathrm{~m}$ above sea level, located at coordinates $28^{\circ} 49^{\prime} 22.24^{\prime \prime}$ Latitude N and $111^{\circ}$ 56'27.13" Longitude West (Figure 1b). The area was selected for its characteristics of soil type saline clay soils and that was no longer used for conventional crops. Within the field, an experimental area of 4,000 $\mathrm{m}^{2}$ was used, which was fenced with cyclonic mesh to prevent the entry of domestic animals. Soil sampling [25] was carried out to analyze the nitrogen content according to the fenolicisulfonic acid method of Allison et al. [26], the phosphorus content, according to Dickman and Bray's molybdenum blue method [27] and salinity [28].

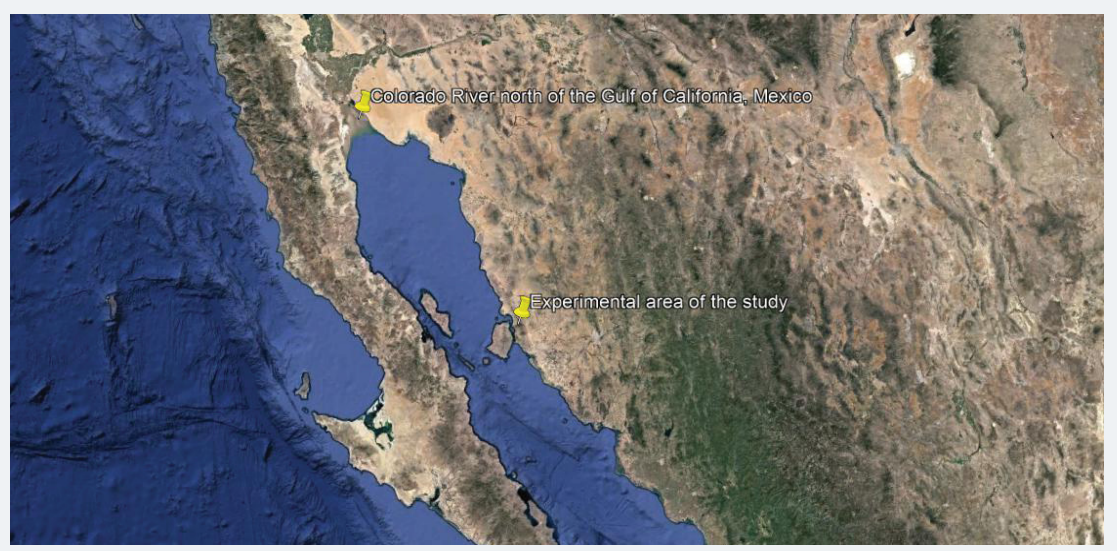

Figure 1: Location of the sampling área and collection of plants of Distichlis spicata in the Delta of the Colorad River north of the Gulf of California, Mexico (a) and experimental area of the study (b). 


\section{Seed preparation and transplant}

An area of seedling production was established (indicated in the experimental area location section), which was prepared using organic material-vermiculite-pedestrian moss (Sunshine, Sun Gro Horticulture Canada, Ltd. Seedling production area was broadcast and covered $(0.5 \mathrm{~mm})$ with "peat moss" [29]. Irrigations were carried out daily at full saturation, which was supplied by a well and according to the classification of Richards [30], cited by Jackson [28], belongs to the fifth class since it contained $16,000 \mathrm{ppm}$ of salts and presented a pH of 8; 0.322-0.328 of Nitrites $\left(\mathrm{NO}_{2}\right) \mu \mathrm{m} / \mathrm{L}$ and 6.22-6.65 of Nitrates $\left(\mathrm{NO}_{3}\right) \mu \mathrm{m} / \mathrm{L}$. Fifty-four days after germination, the transplant was performed, during the month of November oscillating an average temperature during the day of $27 \pm 3^{\circ} \mathrm{C}$ and a diurnal temperature of $18 \pm 3^{\circ} \mathrm{C}$, with an $\mathrm{RH}$ of $73 \%$ The transplant was carried out six days after the application of fertilizers and the first irrigation. 900 seedlings manually with a height of $10 \pm 3 \mathrm{~cm}$ and a separation between $50 \mathrm{~cm}$ seedlings, which were randomly distributed in each plot; the plots had a complete saturation of humidity.

\section{Preparation of the soil}

For the preparation of the land a fallow was carried out at $30 \mathrm{~cm}$, a cross tracking, in order to standardize the particle size, followed by a leveling with a "land plane" equipment according to De La Loma [31]. Later, experimental plots (melgas) of 5 x $5 \mathrm{~m}$ were drawn with an edger.

\section{Fertilization in the corresponding treatments}

The application of fertilizers was developed six days before the transplant, using as a nitrogen source, urea $(46 \% \mathrm{~N})$; and as a phosphorus source, triple superphosphate (46\% P). The fertilization dose was (N-P: 120-60).

\section{Irrigation in the field}

The irrigation water was supplied by the same water well that was used for seedling production. The three risks after transplant were applied every six days and the following every 15 days.

\section{Variables evaluated}

The measurements made were in percentage of emergence and seedling height in nursery. At the field level, at 50, 73 and 144 days after the transplant, seedling height number of basal stems was also evaluated. The following variables were determined at 300 days after the transplant: crude protein, non-protein nitrogen, ammoniacal nitrogen, true protein, neutral detergent fiber, cellular content, hemicellulose, lignin, acid detergent fiber and cellulose. The harvest was done manually at 550 days after the transplant. The maturity of the grain was considered when the spike presented a yellow color and the following data were taken: length of plant, spike and grain, number of spikes per plant and number of seeds per spike. The measurements were made in ten plants per repetition of each treatment, taken at random [32].

\section{Experimental design}

The experimental design used was completely random blocks, with three repetitions per treatment, giving a total of 12 experimental plots. The statistical analysis was performed with the GLM procedure of the SAS computer package [33] and Box [34].

\section{Results and Discussion}

\section{Physical characteristics of the soil in the experimental area}

The results indicate that the percentage of sand that is established is of $62.04 \%$, that of silt is of $22.72 \%$, that of clay was of $15.24 \%$, the established permeability was of high to excessive, the percentage of saturation registered a $31.5 \%$, the apparent density is 
$1.66 \mathrm{~g} / \mathrm{cm}^{3}$, the infiltration capacity is $7.5 \mathrm{~cm} / \mathrm{ha}$, the average electrical conductivity is 3.14 Milimmho, $0.22 \%$ organic matter, potassium (K) is $21 \mathrm{ppm}$, sodium ( $\mathrm{Na}) 247 \mathrm{ppm}$, calcium (Ca) 240 ppm, pH 9.12, field capacity 7.5\%, N-NO $11.8 \mathrm{~kg} / \mathrm{ha}$ and phosphorus $\left(\mathrm{P}_{2} \mathrm{O}_{5}\right)$ at $8.3 \mathrm{~kg} / \mathrm{ha}$.

\section{Emergency rate}

The statistical analysis indicates that among the treatments studied a significant difference was found with $\mathrm{P}<0.05$, where $B$. amilolyquefaciens and the fertilizer treatments stimulated the emergence of $D$. spicata, by 40 and $30 \%$ respectively compared to the control without inoculant and without fertilizer. The maximum emergency values were reached at 28 days with $57 \%$ with $B$. amilolyquefaciens, while that of fertilizer was at 32 days with $47 \%$. For its part, the free control of inoculant and fertilizer was obtained at 43 days with $27 \%$. The above results indicate that bacteria promote germination in D. spicata, possibly due to the ability of bacteria to produce and stimulate the synthesis of hormonal compounds such as gibberellins GA3, which are mentioned by other authors [23,33,34]

\section{Transplant}

The seedlings developed in seedling production area and that were used for the transplant, had a height range of 5 to $16 \mathrm{~cm}$ height, highlighting that the plants treated with B.a., reached an average height of $13 \pm 3 \mathrm{~cm}$ at 50 days, while those treated with fertilizer, presented an average height of $12 \pm 3 \mathrm{~cm}$, there being no significant difference between the two, but the contrary with the control treatment. Also, in all the treatments it was observed that the first leaves of the emerged plants, after 3 or 4 days, a variability in shape and position; these leaves were presented alternately as the stem developed, becoming transparent and chlorotic, ending up drying out in this first stage of seedling production. On the other hand, it was observed, when the seedling reaches approximately $2 \mathrm{~cm}$ in height, an average of 0.8 leaves per centimeter of height is presented, in such a way that a plant of $14 \mathrm{~cm}$ in height contained 9 to 16 leaves, under the conditions of the present study. This is attributed to the genetic variability of the seeds, since according to Renganathan et al. [35]. In halophytes, this type of behavior is usual.

\section{Development of plants in the field}

Considering the different treatments under study, the results of plant height at 50 days after the transplant, the results indicate a significant difference with $P>0.05$ of those treatments inoculated with B.a. and fertilized vs. control. Values indicate that plants treated with B.a. they had a height of $17 \mathrm{~cm} \pm 8$, while the fertilizer-treated showed an average height of $16 \mathrm{~cm} \pm 6$. For its part, the control treatment had a lower height of up to $30 \%$ less compared to the rest treatments.

Regarding the formation of lateral stems, the results indicate that 50 days after the transplant, the plants treated with fertilization and the B.a. bacteria showed no significant differences between treatments; the number of stems ranged from $6 \pm 3$.

At 73 and 144 days after the transplant, the height of the treatments based on B.a. and with fertilizer, they showed an average height of 35 and $44 \mathrm{~cm} \pm 11$, respectively, while those plants without the bacteria and the fertilizer, indicated a height of 27 and $37 \mathrm{~cm} \pm 13$ at 73 and 144 days after transplantation, respectively.

According to the formation of the basal stems, it was observed that in all the treatments in addition to forming the stems were also generating long internodes. The results indicate that at 73 days there was no significant difference between treatments with $P>0.05$, between inoculated and fertilizer-based treatments, while with control treatment if significant differences were shown. The number of stems oscillated between the 20 basal stems \pm 8 in the treated plants. 
A similar behavior in the number of stems at 144 days (with significant difference with $P>0.05$ ), was observed between inoculated and fertilized treatments vs the control; the number of stems oscillated between $90 \pm 7$ basal stems for plants inoculated and fertilzers, while for the control, up to $65 \pm 9$ basal stems were generated.

In table 1 , the results obtained in plants of $D$. spicata can be observed by effect of B. amilolyquefaciens compared with that treatment based on fertility and the control control; the results correspond individually for each plant: crude protein (\%), nonprotein nitrogen (\%), ammoniacal nitrogen (\%), true protein (\%), NDF (\%), cellular content (\%), hemicellulose (\%), lignin (\%), acid detergent fiber (\%) and cellulose (\%). It can be seen that those such as: crude protein, non-protein nitrogen, neutral detergent fiber and acid detergent fiber stand out significantly $(\mathrm{P}>0.05)$, compared to the control control, inoculated treatments based on B.a. and the fertilized.

Regarding length of ear, length of seed, number of seeds per ear, yield per plant and test weight of the seed, the results are presented in table 2 .

During the development of the study, it was possible to observe that the first spikes appeared at 480 days after the transplant, obtaining an average growth length of 10 $\mathrm{cm} \pm 3 \mathrm{~cm}$ (Table 2).

According to the production yield per seed per spike, the results obtained were an average of 42.20 seeds per spike and an average of $42.20 \mathrm{~g}$ seed / plant; the values mean child for the inoculated and fertilized treatments, compared to the control of the work.

The present study indicates that D. spicata is benefited by B.a. and fertilization based on N-P. Results related to plant growth promoting bacteria have been obtained for other plants $[36,37]$ and that, although the tests were carried out with other plants and others beneficial microorganisms, some inhibit the effects on germination [38].

However, other studies show positive effects with this type of microorganism [36,38-40] that also coincide with the results of the present study. The positive effects

Table 1: Nitrogen and fiber fractions of Distichlis spicata inoculated with Bacillus amyloliquefaciens and fertilization (N-P) under field conditions.

\begin{tabular}{|c|c|c|c|}
\hline & $\begin{array}{c}\text { T1: Bacillus } \\
\text { amyloliquefaciens }\end{array}$ & $\begin{array}{c}\text { T2: Chemical fertilization (N-P: } \\
120-60)\end{array}$ & T3: Control \\
\hline Crude protein (\%) & $7.46 \pm 0.43 a$ & $7.44 \pm 0.46 a$ & $6.30 \pm 0.55 b$ \\
\hline Non-protein nitrogen (\%) & $0.56 \pm 0.04 a$ & $0.54 \pm 0.05 a$ & $0.44 \pm 0.06 \mathrm{~b}$ \\
\hline Ammoniacal nitrogen (\%) & $0.02 \pm 0.03 a$ & $0.02 \pm 0.03 a$ & $0.02 \pm 0.03 a$ \\
\hline True protein (\%) & $3.80 \pm 0.28 \mathrm{a}$ & $3.65 \pm 0.19 \mathrm{a}$ & $3.21 \pm 0.26 \mathrm{~b}$ \\
\hline FDN (\%) & $77.69 \pm 6.92 \mathrm{a}$ & $78.98 \pm 6.56 \mathrm{a}$ & $65.98 \pm 5.23 \mathrm{~b}$ \\
\hline Cellular content (\%) & $22.31 \pm 6.88 \mathrm{a}$ & $23.32 \pm 6.78 \mathrm{a}$ & $19.23 \pm 6.33 \mathrm{a}$ \\
\hline Hemicellulose (\%) & $39.25 \pm 6.43 \mathrm{a}$ & $39.20 \pm 6.46 \mathrm{a}$ & $42.32 \pm 0.34 \mathrm{a}$ \\
\hline Lignine (\%) & $6.58 \pm 4.22 \mathrm{a}$ & $6.45 \pm 4.78 \mathrm{a}$ & $7.34 \pm 4.33 \mathrm{a}$ \\
\hline Acid detergent fiber (\%) & $38.44 \pm 1.34 \mathrm{a}$ & $37.34 \pm 1.76 \mathrm{a}$ & $33.45 \pm 1.90 \mathrm{~b}$ \\
\hline Cellulose (\%) & $28.98 \pm 1.55 \mathrm{a}$ & $29.10 \pm 1.44 \mathrm{a}$ & $32.23 \pm 2.12 \mathrm{a}$ \\
\hline
\end{tabular}

T2: nitrogen source, urea $(46 \% \mathrm{~N})$; and as a phosphorus source, triple superphosphate $(46 \% \mathrm{P})$. The fertilization dose was (N-P: 120-60); Mean \pm D.E of analysis in duplicate of five samples. Different literals = significant difference with $P>0.05$.

Table 2: Values of the measurements in plants, ears and seeds of Distichlis palmeri.

\begin{tabular}{|c|c|c|c|}
\hline & $\begin{array}{c}\text { T1: Bacillus } \\
\text { amyloliquefaciens }\end{array}$ & $\begin{array}{l}\text { T2: Fertilización química (N-P: } \\
\qquad 120-60)\end{array}$ & T3: Control \\
\hline Length of the spike $(\mathrm{cm})$ & $15 a$ & $10 a b$ & 7c \\
\hline Seeds per spike & $70 a$ & $45 b$ & $12 c$ \\
\hline Yield per plant (g) & $71.75 a$ & $72.20 \mathrm{a}$ & $23.26 \mathrm{~b}$ \\
\hline Seed length (cm) & $0.80 \mathrm{a}$ & $0.68 a b$ & $0.50 \mathrm{c}$ \\
\hline Hectolytic weight of the seed & $59.52 a$ & $53.48 a$ & $46.67 a b$ \\
\hline
\end{tabular}

T2: nitrogen source, urea $(46 \% \mathrm{~N})$; and as a phosphorus source, triple superphosphate $(46 \% \mathrm{P})$. The fertilization dose was (N-P: 120-60); Mean \pm D.E of analysis in duplicate of five samples. Different literals = significant difference with $P>0.05$. 
of these bacteria observed in the present study apparently are due to the production of growth promoting substances as reported in other studies [39-41]. On the other hand, a fertilization, results that show studies of corn (Zea mays) [42], where fertilizer levels were applied $\mathrm{f}_{2}$, the low concentrations of $\mathrm{NO}_{3}$ detected, the sap was being directed towards the formation of biomass.

The previous results show that the growth of $D$. spicata during the vegetative development was promoted by beneficial bacteria and fertilization. Considering the use of the plant growth promoting bacteria in the present study, the results indicate that it's use can help in the expression of their potential for growth and development, e.g. a greater production of biomass.

It is important to indicate that among the mechanisms of interaction that some authors cite about beneficial microorganisms and plants, is the promotion of growth and development induced by growth regulating substances $[43,44], \mathrm{N}_{2}$ fixation and assimilation as organic nitrogen, enhanced mineral uptake and improved root growth $[34,45,46]$.

\section{Conclusion}

In accordance with the goals, the results obtained and related to the emergence, increases in yield under the given field conditions and due to the beneficial effect of $B$. amilolyquefaciens with $D$. spicata plants, suggest the feasibility of replacing nitrogen fertilizers where biomass and seed production are significant compared with the control treatments. The possible and viable introduction of beneficial bacteria such as $B$. amilolyquefaciens to halotolerant plants with productive potential as $D$. spicata in semi-arid and coastal areas is reaffirmed. Finally, it is important to mention that this type of experimental work contributes to broaden the knowledge in the possible alternatives of agricultural production and effects in the application of biofertilizers in new vegetative materials with productive potential of socio-economic interest for States with problems of water availability of good quality, such as Sonora, in Northwest Mexico.

\section{Acknowledgement}

To the National Council of Science and Technology (CONACyT), PRODUCE Foundation, Secretaría de Agricultura, Ganadería, Desarrollo Rural, Pesca y Alimentación; Comisión Nacional Forestal, for their support and project aproved to Dr. Edgar 0. Rueda Puente, researcher into the University of Sonora.

\section{References}

1. Valiente BA. La conservación de los desiertos: un desafío. PRONATURA. 1996; 4: 34-37.

2. Toledo VM. Ordóñez MJ. El panorama de la biodiversidad en México. Una revisión de los hábitats terrestres. In: Ramamoorthy TP.; R. Bye; A. Lot y J. Fa (Comp.) Diversidad Biológica de México. Instituto de Biología, UNAM. México. 1998; 791.

3. Haro A, J.L. Seminario sobre plantas halófitas. Fenología y Propagación de Distichlis palmeri (Vasey) Depto. de Agricultura y Ganadería. Universidad de Sonora. Hermosillo, Sonora. 1989; 1-5.

4. Araiza QH. Las Plantas Halófitas del Golfo de California. In: memorias del II Congreso Nacional de Halófitas. Memorias. 1988; 4-10.

5. Yensen SB, Weber CW. Composition of Distichlis palmeri Grain, a Saltgrass. J. Food Science. 1986; 51: 1089-1090. Ref.: https://goo.gl/MeaPDS

6. Shreve F, Wiggins IL. Vegetation and flora of the Sonoran Desert. I. Stanford, CA, USA. 1964. Ref.: https://goo.gl/sDjDCZ

7. Gould F, Moran R. The grasses of Baja California, México. Memories 12th. Meeting of the Soc Nat Hist. San Diego, CA, USA. 1981.

8. Horvath J. Distichlis stricta. Saltgrass, desert saltgrass. 2018; Ref.: https://goo.gl/hNwn23 
9. Uchytil, RJ. Distichlis spicata. 2018. USDA, Forest Service, Rocky Mountain Research Station, Fire Sciences Lab. Fire Effects Information. 2018. Ref.: https://goo.gl/BZhBxp

10. Arredondo JT, García-Moya E, Kobashi J. Efecto de la temperatura, el fotoperíodo y la salinidad en el crecimiento y fisiología de Distichlis spicata. Agrociencia 1991; 25: 103-122.

11. Lugg DG. The potential of saltgrass as a forage grass irrigated with saline water. Project No. 1345653. 2018; Ref.: http:// wrri.nms.edu/publish/techrpt/abstracts/abs162.html

12. Martínez B. Producción agraria ecológica. En: Revista de desarrollo rural y cooperativismo agrario. Universidad de Zaragoza. 1996; 5: Ref.: https://goo.gl/N9jzTb

13. Jena $P$, Adhya $T$, Rao V. Nitrogen fixation in Azospirillum sp. isolated from rice and soil as influenced by carbofuran and combined nitrogen Zentralbl Microbiology. 1992; 147: 340-344. Ref.: https://goo.gl/g3jwrd

14. Gamo T, Sang B. Growth-promoting Azospirillum spp isolated from rice roots of several non-gramineus crops in Japan. Soil Science Plant Nutrition. 1990; 37: 455-461. Ref.: https://goo.gl/kMs6f4

15. Okon Y, Labandera G. Agronomic applications of Azospirillum: and evaluation of 20 years worlwide field inoculation. Soil Biology \& Biochemistry. 1994; 26: 1591-1601. Ref.: https://goo.gl/97D2iR

16. Buckman, H. Brady N. Naturaleza y propiedades de los suelos. Ed. Montaner y Simon S.A. España 1977; 589. Ref.: https://goo.gl/mNRC8X

17. De Troch $P$, Vaderleyden J. Surface properties and motility of Rhizobium and Azospirillum in relation to plant root attachment. Microbiology Ecology. 1996; 32:149-169. Ref.: https://goo.gl/RqmyWU

18. Bashan $Y$, Ream $Y$, Levanony $H$, Sade A. Non-specific responses in plant growth, yield, and root colonization of noncereal crop plant to inoculation with Azospirillum brasilense cd. Canadian Journal Botany. 1989; 67: 1317-1324. Ref.: https://goo.gl/2TSy8o

19. Castellanos CT. Respuesta de la superficie de la bacteria promotora de crecimiento de plantas Azospirillum spp. a estímulos externos. Tesis Doctoral. Centro de Investigaciones Biológicas del Noroeste S.C. La Paz, B.C.S. México. 1998; 7.

20. Tarrand J, Krieg N, Bobereiner J. A taxonomic study of the Spirillum lipoferum group, with descriptions of a new genus, Azospirillum gen. Nov. and two species, Azospirillum lipoferum (Beijerinck) comb. Nov. and Azospirillum brasilense sp. Nov. Can J Microbiol. 1978; 24: 967-980. Ref.: https://goo.gl/rH4ip3

21. Magalhaes F, Baldani J, Souto S, Kuykendall J, Bodereiner J. A new acidtolerant Azospirillum species. Academia Brasileña de Ciencias. 1983; 55: 417-430. Ref.: https://goo.gl/jXQg2p

22. Khammas K, Ageron E, Grimont $\mathrm{P}$, Kaiser P. Azospirillum irakense sp. Nov. a nitrogen-fixing bacterium associated with the roice roots and rhizosphere soil. Res Microbiol. 1989; 140: 679-693. Ref.: https://goo.gl/1BrCPF

23. Reinhold, B., Hurek, T., Fendrik, I., Pot, B., Gillis, M., Kersters, K., Thielmans, S. and De Ley, J. Azospirillum halopraeferens sp. nov. a nitrogen-fixing organism associated with roots of Kallar grass (Leptochloa fusca L. Kunth). International Journal of Systematic Bacteriology. 1987; 37:43-51. Ref.: https://goo.gl/65jYRV

24. Carrillo A, Puente $M$, Castellanos $T$, y Bashan Y. Aplicaciones Biotecnologicas de Ecologia Microbiana. Manual de Laboratorio. Pontificia Universidad Javeriana, Santafé de Bogotá, ColombiaCentro de Investigaciones Biológicas del Noroeste La Paz, Baja California Sur, México. 1998; 51.

25. Chapman, H. D. Pratt PF. Método de Análisis para Suelos, Plantas y Agua. Ed. Trillas. México. 1979; 113-114. Ref.: https://goo.gl/1XrLtq

26. Allison EL, Brown JM, Howard HE. Diagnóstico y Rehabilitación de Suelos Salinos y Sódicos. Ed. Limusa. México. 1980; 106.

27. Millar CE, Turk LM, Forth HD. Fundamentos de la Ciencia del Suelo. Editorial CECSA. México. 1981479.

28. Jackson ML. Análisis Químico de Suelos. Ediciones Omega. Tercera Edición. Barcelona España. $1976 ; 350$.

29. Shourbagy MN, Yensen NP. Siembra directa de Distichlis palmeri en suelos irrigados con agua de mar. En: Memoria del VII Simposio Sobre Medio Ambiente del Golfo de California. Loreto, B.C.S., México. 1982; 57-58.

30. Richards E. Guía sobre la Calidad de las Aguas de Riego. Handbook No. 50. Departamento de Agricultura de los Estados Unidos. Washington, D.C. 1954; 80. Ref.:

31. De la Loma LJ. Experimentación Agrícola. Editorial Hispano-Americana S.A. México. 1980; 229. 
32. Glenn EP, Fontes M, Yensen N. Productivity of halophytes Irrigated With Hypersaline Seawater in the Sonora Desert in Biosaline Research. Ed. San Pietro Anthony, Plenum, New York. 1982; 491-494. Ref.: https://goo.gl/pjtejz

33. SAS. SAS/STAT User's Guide 6.08. SAS Institute Inc. Carey, NC, USA. 2001;

34. Tien T, Gaskins M, Hubbell D. Plant growth substances produced by Azospirillum brasilenese and their effect on the growth of pearl millet (Pennisetum americanum L.) Applied Environmental Microbiology. 1979; 20: 1016-1021. Ref.: https://goo.gl/BXQb2v

35. Box GE, William GH, Stuart H. Estadística para Investigadores. Ed. Reverté, Barcelona España. 1993; 363-384. https://goo.gl/zTJACN

36. Zexun L, Wei S. Effect of cultural conditions on IAA biosynthesis by Klebsiella oxytoca SG-11.Chinese Journal of Applied and Enviromental Biolgy. 2000; 6: 66-69. Ref.: https://goo.gl/bXVMae

37. Renganathan $P$, Ruíz-Alvarado $C$, Hernández-Montiel LG, Duraisamy $P$, Rueda- Puente EO. Evaluation of genetic diversity in germplasm of paprika (Capsicum spp.) using random amplified polymorphic DNA (RAPD) markers. J Plant Sci Phytopathol. 2017; 1: 080-086. Ref.: https://goo.gl/dhbdDo

38. Puente M, Bashan Y. Effect of inoculation with Azospirillum brasilense strains on germination and seedlings growth of the giant columnar cardon cactus (Pachycerus pringler). Symbiosis. 199315 49-60. Ref.: https://goo.gl/1Sgf1W

39. Goodfriend WL, Olsen MW, Frye RJ. Soil microfloral and microfaunal response to Salicornia bigelovi planting density and soil residue amendment. Plant and Soil. 2000; 1: 23-32. Ref.: https://goo.gl/sCPm8U

40. Díaz V, Ferrera C, Almaraz S, Alcántar G. Inoculation of plant growth-promoting bacteria in lettuce. Terra. 2001; 19: 327-335. Ref.: https://goo.gl/3rdhhR

41. Arsac J, Lamothe C. Fages J. Growth enhancement of Maize (Zea Mays) through Azospirillum lipoferum inoculation: effect of plant genotype and bacterial concentration. Agronomie. 1990; 10: 640-654. Ref.: https://goo.gl/ii7FZg

42. Puente M, Holguin G, Glick B, Bashan Y. Root-surface colonization of black mangrove seedlings by Azospirillum halopraeferens and Azospirillum brasilense in seawater. Microbiol. Ecology. 1999; 29: 283-292. Ref.: https://goo.gl/uA9d3Z

43. El-khawas $\mathrm{H}$, Adachi K. Identification and quantification of auxins in culture media of Azospirillum and Klebsiella and their effects on rice roots. Biology and Fertility of Soils. 1999; 29: 377-381. Ref.: https://goo.gl/rw4ugG

44. Pérez-Silva R. Influencia de diferentes niveles de nitrógeno y poblaciones de plantas sobre los rendimientos de maíz (Zea mays L.) Agronomía Tropical. 1989; 27: 451-459. Ref.: https://goo.gl/rH54xE

45. Itai $C$, Richmond $A$, Vaadia $Y$. The role of root cytokinins during water and salinity stress. Journal Botany. 1968; 63: 694-701.

46. Khan M, Khan I, Khizar T. Plant growth regulators from species differing in salt tolerance as affected by soil salinity. Plant Soil. 1976; 45: 269-276. Ref.: https://goo.gl/vSvVib

47. Conrad K, Bettin B, Neumann S. The cytokinin production of Azospirillum and Klebsiella possible ecological effects. In: M. Kaminek et al. (eds), Physiology and biochemistry of cytokinins in plants. Symposium Liblice, República de Checoslovaquia. 1992; 401-405.

48. El-Shatnawi MKJ, Makhadmeh I. Ecophysiology of the Plant-Rhizosphere System. Journal Agronomy and Crop Science. 2001; 187: 1-9. Ref.: https://goo.gl/hjb3ca 